2013s-11

\title{
Dynamic Effects of Credit Shocks in a Data-Rich Environment
}

\author{
Jean Boivin, Marc P. Giannoni, Dalibor Stevanović
}

Série Scientifique
Scientific Series

\begin{abstract}
Montréal
Mai 2013
\end{abstract}

(C) 2013 Jean Boivin, Marc P. Giannoni, Dalibor Stevanović. Tous droits réservés. All rights reserved. Reproduction partielle permise avec citation du document source, incluant la notice $($ ).

Short sections may be quoted without explicit permission, if full credit, including (C) notice, is given to the source.
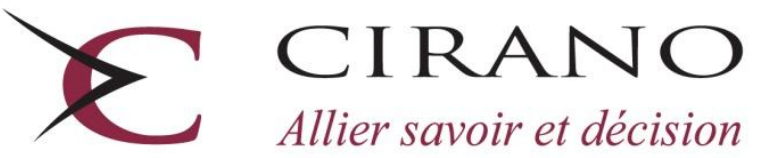

Allier savoir et décision

Centre interuniversitaire de recherche en analyse des organisations 